\title{
Tom Gibson - Surgical giant with great vision
}

\author{
Martin A Entin MD \\ Royal Victoria Hospital, Montreal, Quebec
}

$\mathrm{T}$ he passing of Professor Thomas Gibson of Glasgow, on February 13, 1993, brought to a close the life of a true scientist endowed with many talents. From the moment he received his medical degrees from Glasgow University in 1938, Tom was involved in the scientific, clinical, cultural, educational and historical aspects of surgery in Great Britain.

Tom Gibson was born in Kilbarchan, Scotland, on November 24, 1915, and attended school at the Paisley Grammar School nearby. He subsequently attended Glasgow University Medical School and received his medical degree, with commendation, in 1938. Following the usual training he was appointed to the Burn Unit of the Glasgow Royal Infirmary as assistant surgeon in 1942. In 1944, Gibson joined the Royal Army Medical Corps, serving in northern Europe and in India with the Maxillofacial Unit. At the time of his demobilization in 1947, he had attained the rank of Major and became consultant in plastic surgery at the West of Scotland Plastic and Oral Surgery Service, at the Glasgow Royal Infirmary. Gibson became Director of Service at the Canniesburn Hospital in 1970, and served until his retirement in 1980.

While serving as assistant surgeon at the Medical Research Council Burn Unit in the early 1940s, Gibson began to experiment with exchange of tissue between nonrelated animals. After some experiments, he was the first to recognize that the homograft rejection phenomenon was the result of immunological reaction. A young graduate student at Oxford, Peter Medawar, who was interested in this area of research, joined Gibson in Glasgow and collaborated with him on some experiments. In 1943, they published a paper, 'The Fate of Skin Homographs in Man', which established that homograft rejection was due to antigen-antibody reaction $(1,2)$. In 1960, Medawar, who pursued this work further, received the Nobel Prize in this important area of experimentation. Medawar acknowledged his debt to Gibson for giving him the first insight into this work.

Later, Gibson's interest was attracted by the behaviour of cartilage transplantation. He found that the warping of cartilage was due to disturbance of the integrity of the perichondrium. He noted that if the cartilage was completely denuded of perichondrium or if the perichondrium was left intact, the

Correspondence: Dr Martin Entin, Royal Victoria Hospital, 687 avenue des Pins ouest, Montréal, Québec H3A IAI. Telephone (514) 842-1231

cartilage architecture was not distorted. He also found that autogenous cartilage cells survive transplantation (3-7). Gibson's interest in the behaviour of tissues in vivo and in transplantation made him realize that fundamental principles of bioengineering were affecting the reaction of most tissues. In collaboration with Professor Robert Kenedi, he founded the BioEngineering unit at Strathclyde University in 1960 . Their studies applied engineering princi-

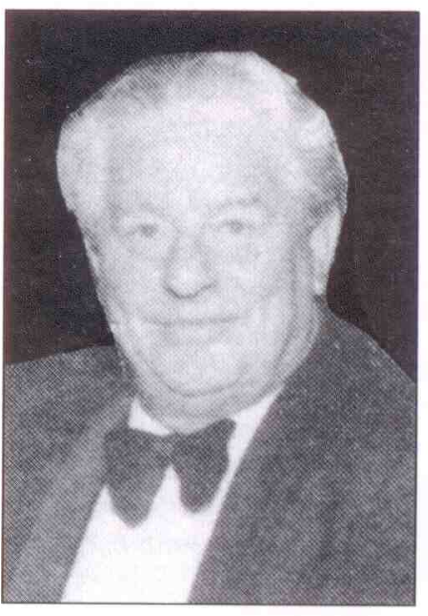

Tom Gibson during his visit to North America in 1972 ples to medicine and surgery and clarified a number of puzzling aspects of tissue behaviour (8-11).

\section{VISIT TO GLASGOW}

In 1955, I had the pleasure of visiting the Glasgow Royal Infirmary as part of a travelling fellowship under aegis of the American Foundation of Plastic and Reconstructive Surgery (12). In the absence of the head consultant of the Plastic Surgery Unit, Tom Gibson was appointed to be my host. He threw all the hospital facilities, his home and his children at my disposal. A wealth of clinical material was seen at the Royal Infirmary and at the Ballochmyle Plastic Surgery Centre. Glasgow was known for its reconstructive work in lymphedema and for the skilful handling of maxillofacial injuries. The dental department there, as in many other centres I visited, formed an integral part of the unit, so that ingenious and useful gadgets were available at a moment's notice for the treatment of severe injuries of the head and face.

\section{THE HUNTER MUSEUM}

In addition to meeting Tom Gibson during my visit to the Royal Infirmary and the Glasgow University, there were other fringe benefits. First was the Hunterian Museum which I knew was collected by William Hunter himself, consisting of anatomical and pathological specimens and rare books. William Hunter, John's lesser known elder brother (1718- 
1783), was a scientist and anatomist in his own right. He later became a specialist in obstetrics and practised in London. He attended Queen Charlotte, wife of George III, in her first confinement in 1762 . Hunter finally donated this museum to the University of Glasgow, his Alma Mater, in 1781 (13).

A special building was erected to house Hunter's collection in 1807 . When the university was finally moved to the west end, the pathological collection of over 2500 specimens had to be housed in the department of pathology of the Glasgow Royal Infirmary. I was privileged to have Tom Gibson show me around this voluminous collection, which represented a compact review of the history of pathology.

On one weekend I accompanied the Gibson family in their car on a special visit to the Royal Borough of Inveraray. The town faces Loch Fyne and was regarded as the best example of late 18th century town planning in Scotland. The borough was owned by the Dukes of Argyll for several generations. The seat of the current Duke was at the Inveraray Castle, just to the north of town. We were able to visit the lovely castle where we had afternoon tea and scones.

\section{JAMES McGILL}

Although I knew that James McGill had attended the University of Glasgow during the last quarter of the 18th century, I was quite surprised to find a large plaque on the wall of the University. It stated that James McGill had attended the University of Glasgow for two years and had interrupted his education to emigrate to Canada. The plaque did not state the reason was that he was short of money.

James McGill did well in Canada. He amassed a fortune, became the Magistrate of Montreal, was in charge of the militia and was elected member of parliament. McGill participated in all phases of commercial, administrative and cultural life of Montreal. As early as 1801, McGill made a decision to use his money to found a college. He applied to the government for a charter for the establishment of the Royal Institution for Advancement of Learning. In 1811, he bequeathed the sum of 10,000 pounds (about 1 million dollars in today's money) and his 46 acre Burnside farm for the founding of this college. Although McGill spent only two years at the University of Glasgow, it affected very strongly his attitude and philosophy of life. When he died in 1813, he left most of his possessions for the establishment of the new university with a proviso that is must be functioning within 15 years of his death, otherwise the money would revert back to his heirs (14).

I was delighted that Tom Gibson was aware of the story of McGill university and the Glasgow heritage. Gibson's own career was as varied as that of McGill. From the time he became a fellow of the Royal College of Physicians and Surgeons of Glasgow in 1955, Gibson maintained a lively interest in the activities of the college. He was member of council from 1964 to 1979, served as honorary librarian, and was elected president of the Royal College for 1976 and 1978.

Two years after my memorable visit to Glasgow, I invited Gibson to be my guest in Montreal. This was Gibson's first

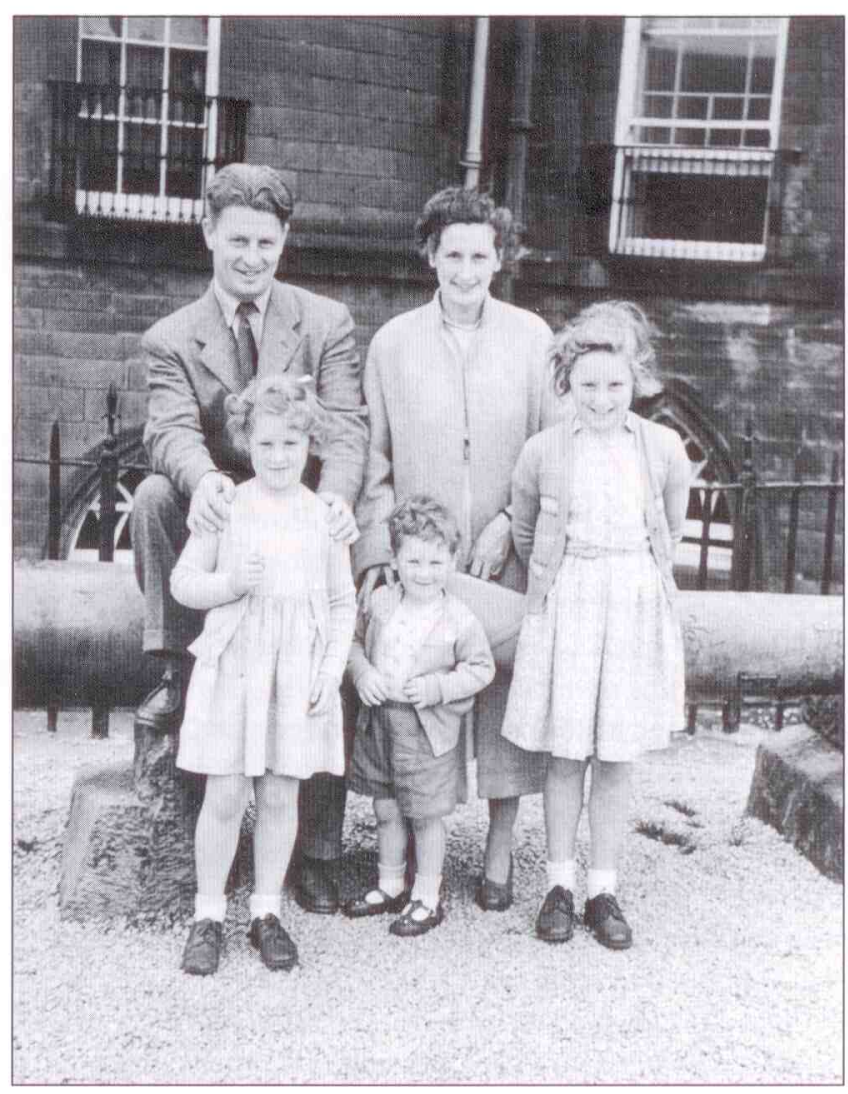

Tom Gibson, wife of Pat, and three of their four children on a visit to Argyll Castle in 1955

trip to Montreal and McGill University. We gave him the VIP tour of the University, including a visit to the Osler Library and the Shriners Hospital for Crippled Children. He took part in the Royal Victoria Hospital Ward Rounds and gave a presentation on the surgical correction of lymphedema of the lower limb which he pioneered. In very severe cases Gibson recommended removal of the entire skin of the leg, except for the foot. After meticulously removing the fat, the thin skin was reapplied to the leg circumferentially, like a skin graft (15-17).

My encounter with Gibson at the Glasgow Royal Infirmary established a lifetime friendship. We became particularly close after the 1959 visit to the Gibson's family summer home in Tighnabruaich in northern Scotland. During the late morning, I would accompany the three older children to the seashore to gather muscles, cockles and seashells. By lunch time, I would acquire a real Glaswegian burr, through instant mimicry, much to the amusement of my wife, Laura. During the same year, we attended the Second International Congress of Plastic Surgery in London. Sir Archibald MacIndoe, the renowned plastic surgeon, who was president of the congress, had some difficulty in accommodating the Russian scientific presentations which were brought unannounced to the congress. They had expectations of being magically fitted into a program which had taken four years to organize.

Although a special room was set aside at the congress to accommodate the presentations of the Russian delegates, 
there was a sense of strain in their general attitude. Tom Gibson and I, with the help of a couple of Western plastic surgeons who spoke French, German and Russian, finally broke up the Russian contingent into small groups during the Lord Mayor's reception at the Guildhall. The display of the Magna Carta and other precious relics created an atmosphere conducive to international understanding.

Gibson's interest in scientific writing led to his appointment as editor of the British Journal of Plastic Surgery in 1969, a position which he held up to 1979 . He was elected president of the British Association of Plastic Surgery in 1970.

The writing of verse was of particular interest and amusement to Gibson. He wrote an amusing but medically accurate

\section{REFERENCES}

1. Gibson T, Medawar PB. The fate of skin homographs in man. J Anatomy Lond 1943;77:299.

2. Gibson T, Medawar PB. Homografts. In: Gibson T, ed. Modern Trends in Plastic Surgery II. London: Butterworths; 1.

3. Gibson T, Davis WB. The long-term survival of cartilage homografts in man. Br J Plast Surg 1958;11:177.

4. Gibson T. Cartilage grafts. Br Med Bull 1965;21:153.

5. Gibson T. Biomechanics in plastic surgery. In: Kenedi RM, ed. Proceedings of Symposium on Biomechanics and Related Bio-Engineering Topics, Glasgow, September 1964. London: Pergamon Press; 1965,129.

6. Gibson T. Developments and applications of biomedical engineering in clinical surgery. Bio-Medical Engineering, June 1966, 304.

7. Gibson T. The transplantation of cartilage. Symposium on Tissue Organ Transplantation. J Clin Path 1967;20(suppl):513.

8. Gibson T, Kenedi RM. The significance and measurement of skin tension in man. Third International Congress of Plastic Surgery in Washington. Baltimore: Williams \& Wilkins; 1963. ode to the skin called 'Stratified Squamous Skin'. This poem was based on the fact that under the microscope a cross section of skin reveals several layers or strata running parallel to the surface; hence stratified (18). Gibson had a profound interest in the history of medicine and particularly in the pioneers of plastic surgery. He was a prolific writer on a wide variety of subjects pertaining to plastic reconstructive surgery and to the behaviour of different tissues under varied conditions. Gibson published 144 articles, reviews and chapters in books.

With Gibson's passing, we have lost a surgical giant with great vision, accumulated wisdom and an uncanny capacity to combine several disciplines to enhance advances in plastic and reconstructive surgery.

9. Gibson T, Kenedi RM. Biomechanics in plastic surgery. Surgery Forum 1963;14:478.

10. Gibson T, Barbenel JC, Evans JH. Quantitative relationships between structure and mechanical properties of tendon. Digest 9th ICMBE, Melbourne, Australia; 1971, 150.

11. Lister GD, Gibson T. Closure of rhomboid skin defects: Flaps of Limberg and Dufourmente. Br J Plast Surg 1971;25:300.

12. Entin MA. A visit to plastic surgery centre. J Plast Surg 1957;19:441-57.

13. Buchanan WW. William Hunter (1718-1783), the almost forgotten Hunter brother. Ann R Coll Phys Surg Canada 1993;26:89-93.

14. Frost S. McGill University for the Advancement of Learning. Vol I, 1801-1895. Montreal:McGill-Queens Press, 1980; 63-5.

15. Gibson T, Tough JS. The surgical correction of lymphoedema of the legs. Br J Plast Surg 1954;7:195.

16. Gibson T, Tough JS. Simplified one-stage technique for the treatment of lymphoedema of the legs. Arch Surg 1955;71:809.

17. Gibson T, Clodius L. In: Watson J, ed. Operative Surgery. John Watson. Butterworths:London; 1979.

18. Gibson T. Stratified squamous skin. Br J Plast Surg 1972; 25:1-2. 